\title{
Meta-analysis of Heavy Metal and Arsenic Ecological-risk Assessment and Sources in Surface Sediments of Lake Wuliangsuhai, China
}

Huaijie He

Hohai University https://orcid.org/0000-0002-7883-0624

Ling Liu ( $\sim$ lingliu_2019@163.com )

Hohai University

Wenming Yan

Hohai University

\section{Research Article}

Keywords: Lake Wuliangsuhai, Heavy metal, Geoaccumulation index, Potential ecological risk, Toxicity units, Positive matrix factorization (PMF)

Posted Date: November 3rd, 2021

DOl: https://doi.org/10.21203/rs.3.rs-945105/v1

License: (c) (1) This work is licensed under a Creative Commons Attribution 4.0 International License. Read Full License 
1 Meta-analysis of heavy metal and arsenic ecological-risk assessment and sources in

2 surface sediments of Lake Wuliangsuhai, China

3

4 Huaijie $\mathrm{He}^{1}$, Ling Liu ${ }^{1,2 *}$, Wenming Yan $^{1,2}$

5

$6 \quad{ }^{1}$ College of Hydrology and Water Resources, Hohai University, Nanjing, 210098, China

$7 \quad{ }^{2}$ State Key Laboratory of Hydrology Water Resources and Hydraulic Engineering, Hohai

8 University, Nanjing, 210098, China

9

$10{ }^{*}$ Corresponding author:

11 Dr. Ling Liu: lingliu_2019@163.com

12

13

14

15

16

17

18

19

20

21

22

23

Submitted to Wetlands

24

September 24, 2021 


\section{Abstract}

Heavy metal and arsenic (As) concentrations in the overlying water of Lake WLSH from 2013-2017 to evaluate the water quality of the lake. Heavy metal and As concentrations in Lake WLSH surface sediment from studies performed between 2009-2017 were analyzed of heavy metal geo-accumulation, potential ecological risk and toxicity data for Lake WLSH surface sediment was performed to allow heavy metal and As pollution of Lake WLSH surface sediment to be described clearly, objectively, and comprehensively. The following four main conclusions were drawn. (1) The water quality index of the overlying water showed a tendency of slight pollution in the lake from 2013 to 2017. (2) Pollution by the heavy metals $(\mathrm{Cu}, \mathrm{Zn}, \mathrm{Pb}$, $\mathrm{Cd}, \mathrm{Cr}$ ) and As in Lake WLSH should be given increased attention. (3) The geoaccumulation indices showed that $\mathrm{Cd}$ is the most critical pollutant and that the probabilities of Lake WLSH sediment being slightly polluted and moderately polluted were found to be $72.8 \%$ and $11.3 \%$, respectively. (4) $\mathrm{Cd}$ is the main contributor $(75.2 \%)$ to potential ecological risks, and although As is at a low toxicity level, its toxicity-risk contribution is higher than that of other metals (approximately 31\%). (5) Positive matrix factorization (PMF) model results indicated that industrial and agricultural resources are the main suppliers of heavy metals to Lake WLSH sediment, contributing $43.2 \%$ and $42.6 \%$ of the heavy metals and As. The summarized results and conclusions can help the local government further understand heavy metals and As pollution in Lake WLSH and develop corresponding pollution-control measures. This study can also serve as a reference for future research on the heavy metals and As pollution of sediment in Lake WLSH and other lakes.

Keywords: Lake Wuliangsuhai, Heavy metal, Geoaccumulation index, Potential ecological risk, Toxicity units, Positive matrix factorization (PMF) 


\section{Introduction}

50 Lakes are indispensable wetlands for the global ecosystem and play important roles in regulating river-water volume and improving the ecological environment (Liu et al., 2020). In recent years, with the changes in regional climate and environment and the aggravation of human activities, lake-ecosystem degradation, water eutrophication, and water pollution have become major global problems (Yang et al. 2008; Nazari-Sharabian et al. 2018; Benateau et al. 2019). In developing countries such as China, the rapid industrial and agricultural growth, as well as other human activities, have led to rising levels of heavy metals in river and lake sediments (Zhang et al. 2016; Yan et al. 2018). Accordingly, heavy-metal and As pollution in aquatic environment has become a research hotspot because of its toxicity, persistence, and bioaccumulation to the environment, as well as its adverse effects on organisms and the entire ecosystem (Lin et al. 2016). Lake sediment, as an important part of water ecosystem, provide habitats and food sources for benthic organisms and also serve as secondary sources and reservoirs of heavy metals in water (Yi et al. 2011). To protect the ecological security of lakes, it is important to study the content of heavy metals and As in lake sediments and the associated pollution information (Rai 2008; Wang et al. 2015).

However, when water-environment factors (such as temperature, $\mathrm{pH}, \mathrm{DO}$, etc.) change, heavy metals and As in sediments may be released into the overlying water and cause continuous water pollution ( $\mathrm{Li}$ et al. 2013; Ali et al. 2016; Barrett et al. 2019). Benthic organisms can accumulate pollutants by ingesting sediments, and further enrich (i.e., $\mathrm{Hg}, \mathrm{Se}$ ) and transfer heavy metals and As through the food chain, which will eventually harm human 70 health (Förstner and Prosi 1979; Yi et al. 2011; Barrett et al. 2019). Accordingly, the distribution rules and environmental risks of heavy metals and As in surface sediments of lakes have been studied, and corresponding measures have been taken to control heavy metals and 
As pollution in lakes and avoid serious environmental risks (Bai et al. 2011; Fu et al. 2013; Hou et al. 2013; Ke et al. 2017).

Lake WLSH, located at the end of Hetao Irrigation District (HID), receives agricultural irrigation drainage, industrial wastewater, and urban sewage of the whole irrigated area (Feng et al. 2005; Xu et al. 2009; Liu et al. 2015). Hence, industrial wastewater from paper mills, domestic sewage and pesticides and fertilizers used in farmland enter the lake after pooling in drainage ditches, and the water bodies contain large amounts of heavy-metal pollutants, As, and nutrients. Farmland-irrigation return flow is the main water source of the Lake WLSH, accounting for more than $90 \%$ of the total water supply (Liu et al. 2015; Lou et al. 2020). Heavy metals, As, nitrogen, and phosphorus nutrient elements, as well as organic matter, enter the lake, resulting in the deterioration of its aquatic ecological environment (Shi et al. 2020a; Wen et al. 2020).

Different heavy metal and As concentrations have been found in different studies of the Lake WLSH. For example, the mean As concentration in Lake WLSH sediment was about 6 times higher in a study published in Lv (2018) than in a study published in Zhang (2010). Liang (2019) and Zhao (2013) found that Cd was the main indicator of potential ecological hazards in Lake WLSH, but Zhang (2010) found that As was the main indicator of ecological hazards in Lake WLSH. There are obvious spatial variations in heavy metal and As concentrations in the sediment of Lake WLSH due to variations in heavy metal and As inputs, seasonal variations, and spatial variations in conditions such as $\mathrm{pH}$ and salt concentrations (Zhang 2010; Zhao 2013; Lv 2018; Liang 2019). These variations make it difficult for those who govern the Lake WLSH to understand heavy metals and As contaminations in lake sediment and to develop pollution prevention strategies. Therefore, a better method is needed to describe the heavy metal and As pollution in Lake WLSH sediment. 
Meta-analysis was first applied in the medical field; when making clinical treatment decisions, the analysis results of this method have often been used as reference data (Simpson and Pearson 1904). It is a powerful study design that combines existing published and unpublished studies to pool the effects of interventions (e.g., drugs, devices, surgeries, and treatment strategies) on clinical and intermediate outcomes (Hernandez et al. 2020). It can

102 reduce the likelihood of bias in the selection of studies, assessment of risk of bias, and outcome 103 definition, as well as the timing and conduct of planned analyses (Vale et al. 2020). Metaanalysis is gradually being applied to other research fields. The comprehensive impact of experiments alone on the ecological environment and the heavy metals potential ecological-risk assessment of the surface sediments in a lake are limited (Kumar et al. 2019; Niu et al. 2020). The use of meta-analysis to analyze environmental pollution data has recently been started to enable comprehensive analyses of pollution. For example, Shao et al. (2016) have integrated the current situation and temporal trend of heavy metals in farmland soil in the Yangtze River delta region through meta-analysis. Zhou et al. (2016) integrated changes in organic carbon and

111 nitrogen in metal-contaminated soils with $\mathrm{Cd}, \mathrm{Cu}, \mathrm{Pb}$, and $\mathrm{Zn}$ through a meta-analysis. 112 Therefore, meta-analysis and statistical methods can be used to compare and integrate the

113 results of multiple studies and subsequently draw conclusions on general patterns at regional or 114 global scales (Gao et al. 2019). Lake WLSH is an extremely rare large multifunctional lake in arid grassland and desert areas worldwide, and the largest wetland at the same latitude on earth (Zhang et al. 2012).

117 Therefore, it is necessary to collect available data based on the concentration and distribution 118 of heavy metals $(\mathrm{Cu}, \mathrm{Zn}, \mathrm{Pb}, \mathrm{Cr}, \mathrm{Cd})$ and $\mathrm{As}$ in the surface sediments of Lake WLSH to comprehensively assess the levels and potential ecological risks of heavy-metal and As contaminations in Lake WLSH. In the present study, available data based on the concentration

121 and distribution of certain heavy metals $(\mathrm{Cu}, \mathrm{Zn}, \mathrm{Pb}, \mathrm{Cr}, \mathrm{Cd}$ and $\mathrm{As})$ in the surface sediments 
of Lake WLSH were collected to assess heavy-metal and As pollution levels and potential

123 ecological risks. The main objectives of this work were as follows: (1) determine the spatial

124 distribution of heavy metals and As in the surface sediments of Lake WLSH by collecting data

125 from published papers; (2) use the $I_{\text {geo, }}$, potential ecological $R I$ assessment, and $T U$ to assess the 126 pollution levels and potential ecological risks of heavy metals and As in the surface sediments 127 of the lake; and (3) use positive matrix factorization model (PMF) to analysis the possible 128 sources of heavy metals and As in the lake sediments.

\section{Methods}

\section{Characteristics of the Lake WLSH}

132 Lake WLSH is located in Wulateqian Banner, county of Bayannaoer Municipality, Inner

133 Mongolia $\left(108^{\circ} 43^{\prime}-108^{\circ} 57^{\prime} \mathrm{E}, 40^{\circ} 36^{\prime}-41^{\circ} 03^{\prime} \mathrm{N}\right)$, is the most typical shallow grass-type lake in 134 the arid zone of Inner Mongolia Plateau, is also one of the eight major freshwater lakes in China, 135 and is called the "Pearl of the Sierra" (Yu et al. 2012; Yang et al. 2014). The lake is long from 136 north to south and narrow from east to west, with an existing area of $285.38 \mathrm{~km}^{2}$, including $137118.97 \mathrm{~km}^{2}$ of reed area and $111.13 \mathrm{~km}^{2}$ of open water area (no reeds), and 250 330 million $138 \mathrm{~m}^{3}$ of lake capacity, with an average elevation of $1018.5 \mathrm{~m}$. The depth of the lake is mostly 139 concentrated in 1.2 2.2 m, with an average depth of $1.78 \mathrm{~m}$. According to the eutrophication 140 rating and the grading standards, the overall nutrient level in Lake WLSH is mid-eutrophic 141 (Yang et al. 2014), and the annual average deposition depth was $9.61 \mathrm{~mm}$ (Yu et al. 2012). The 142 inlet and outflow channels around Lake WLSH are shown in Fig. S1 (Supplementary materials).

143 Since 2000, industries around Lake WLSH (paper mill, pharmaceutical factory, and smelter, 144 etc.) have developed rapidly in an attempt to develop the local economy, and the lake, which

145 receives industrial, agricultural, and residential wastewater, has gradually been polluted (Zhang 146 2010; Inner Mongolia Autonomous Region Bureau of Statistics 2020). 


\section{Data collection}

149 The following databases were used to retrieve published literature: ISI Web of Science for

150 searching English literature, China National Knowledge Infrastructure, and Wan Fang Data for 151 searching Chinese literature (Fig. 1a). The search terms " 'Wuliangsuhai' or 'Ulansuhai' " and

152 "metal" were used in the databases, covering studies from 2000 to 2019 . To ensure data integrity 153 and continuity, 12 of 172 papers were selected to obtain the data of heavy metals in sediment 154 from 2009 to 2017. In this paper, Lake WLSH was divided into entrance, central, and exit zones 155 based on lake hydraulics and inlet channel flows in the selected literature, as described in 156 Supplementary Materials. The criteria for selecting published literature in this research were as 157 follows: (i) the publications that were selected for this research should involve the investigation 158 of the surface sediments $(5-20 \mathrm{~cm})$ in the entire Lake WLSH (i.e., the entrance, central, and exit 159 zones), as shown in Fig. 1b; (ii) the selected literature included sampling information (i.e., 160 sampling date, number of samples, sampling site location, and measured heavy-metal and As 161 concentration), and (iii) the heavy-metal and As concentrations were determined using the same 162 or similar standards.

Figure 1 is here.

\section{Data processing}

166 Evaluation method of overlying water quality

167 Single-factor pollution-index method involves measuring the concentration of a pollutant

168 followed by comparing the pollutant evaluation criteria to determine the water-quality category

169 (Cheng et al. 2002). Through the single-factor pollution-index evaluation, we can determine the

170 main heavy-metal pollution factors in the lake overlying water bodies. The statistical 171 description of heavy metal guideline values for overlying water in selected publications are 
172 shown in Tab.1. Based on the water-quality index (WQI), the comprehensive pollution-index

173 method takes the heavy metals observed at the same measuring point as a whole to study their

174 influence on the environment under the condition of interaction (Bewers 1995; Cheng et al.

175 2002). Equations are as follows:

$$
P_{i}=C_{i} / S_{i}
$$

$$
\mathrm{WQI}=\frac{1}{n} \sum_{i=1}^{n} P_{i}
$$

$P_{i}$, represents the pollution index of $i^{\text {th }}$ heavy metal and As. $C_{i}$ represents the measured concentration of the $i^{\text {th }}$ heavy metal and As $\left(\mu \mathrm{g} \mathrm{L}{ }^{-1}\right) . S_{i}$, represents the evaluation standard of heavy metal and As $\left(\mu \mathrm{g} \mathrm{L}^{-1}\right)$. Surface water environmental quality standards was used Chinese GB3838-2002, in which the standard limits of $\mathrm{Cu}, \mathrm{Zn}, \mathrm{Pb}, \mathrm{Cd}, \mathrm{Cr}$ and As are 1000, 1000, 50, 5, 50 and $50 \mu \mathrm{g} \mathrm{L}^{-1}$, respectively. $n$ is the number of heavy metals and As. WQI consists of three grades as follows (Bewers 1995; Cheng et al., 2002): $1<W Q I \leq 2$, light pollution; $2<W Q I \leq 3$, moderate pollution; $W Q I>3$, heavy pollution.

Evaluation method of heavy metals and As in sediments

Relying solely on chemical analysis to provide ecotoxicological risks associated with trace element contamination is somewhat inadequate (Adams et al. 2005; Allen Burton 2018). However, this is currently still a relatively general screening method that can provide a guide

190 for lake sediment pollution management (Allen Burton 2018). The level of enrichment and

191 toxicity risk of heavy metals and As in the sediments of Lake WLSH were evaluated using the $192 I_{\text {geo, }}$, potential ecological $R I$, and $T U$. The evaluation methods of $I_{g e o}, R I$, and $T U$ were as follows. $I_{g e o}$ is primarily used to assess the degree of heavy-metal and As pollution by deducting

194 sediment or soil background content from the measured heavy-metal and As content. The $I_{g e o}$ 195 of heavy metals and As was calculated as follows: 


$$
I_{\text {geo }}=\log _{2}\left(\frac{C_{n}}{1.5 B_{n}}\right)
$$

where $C_{n}$ is the concentration of the $n^{\text {th }}$ heavy metal and As measured in sediment. $B_{n}$ is

198 the background value of the $n^{\text {th }}$ heavy metal and As. The correction coefficient of factors such

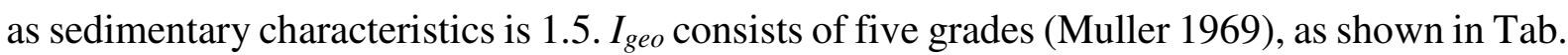
2. caused by the total pollution of the Lake WLSH (Hakanson 1980), as shown in Tab. 2.

$$
E_{r}^{i}=T_{r}^{i} \times C_{s}^{i} / C_{n}^{i}
$$

$$
R I=\sum_{i=1}^{n} E_{r}^{i}
$$

$E_{r}^{i}$ is the ecological-risk coefficient of individual elements. $R I$ is the potential ecological

risks. $C_{s}^{i}$ is the measured concentration of the $i^{\text {th }}$ heavy metal and As in sediment $\left(\mathrm{mg} \mathrm{kg}^{-1}\right) . C_{n}^{i}$ is the background values of the $i^{\text {th }}$ heavy metal and $\mathrm{As}\left(\mathrm{mg} \mathrm{kg}^{-1}\right) . T_{r}$ is the toxic response factor 208 for a given heavy metal and As, i.e., 5, 5, 5, 30, 10 and 5 for $\mathrm{Cu}, \mathrm{Zn}, \mathrm{Pb}, \mathrm{Cd}, \mathrm{Cr}$ and $\mathrm{As}$ respectively. $T U$ evaluation method can be used to determine the influence of heavy metals and As in sediments on water environment (Pedersen et al. 1998). $T U$ 's were calculated to normalize the toxicity induced by various heavy metals and As, then determine the toxic effects of the corresponding elements by comparison with reference ratios. $T U$ can be defined as the ratio of measured concentration $\left(C_{i}\right)$ to probable effect level $(P E L)$ or probable effect concentration 215 (PEC) value $\left(P_{i}\right)$ (MacDonald et al. 2000), as shown in Eq. 6 (Pedersen et al. 1998; MacDonald et al. 2000). The sum of $T U$ 's ( $\Sigma T U)$ is the sum of $T U_{i}$ (Niu et al. 2015).

$$
T U_{i}=C_{i} / P_{i}
$$


$T U$ consists of three grades as follows: $\Sigma T U<4$, low toxicity level; $4 \leq \Sigma T U \leq 6$, moderate toxicity level; and $\Sigma T U \geq 6$, high toxicity level (Pedersen et al. 1998).

\section{Positive Matrix Factorization (PMF) Model}

Paatero first proposed the PMF model in 1994, and the method was approved by the U S

Environmental Protection Agency for identifying air pollution sources (Paatero 1997). The greatest advantage of the PMF model is that no source profiles are required, and uncertainty is used to weight all the data (Niu et al. 2020). Potential sources of heavy metals and As in WLSH

Lake sediments were identified using the PMF 5.0 model, and pollution sources were analyzed using the distribution of five heavy metals and As in Lake WLSH. The aim of the PMF model is to use the concentration and source profiles of the species of interest to solve the mass balance of the species of interest, the calculation equations are as follows (Norris et al. 2014).

$$
x_{i j}=\sum_{k=1}^{P} g_{i k} f_{k j}+e_{i j}(i=1,2,3 \mathrm{~L} \mathrm{n} ; j=1,2,3 \mathrm{~L} \mathrm{~m})
$$
represents the sample. function Q, and Q is a critical parameter for PMF (Norris et al. 2014).

$$
Q=\sum_{i=1}^{n} \sum_{j=1}^{m}\left[\frac{x_{i j}-\sum_{k=1}^{p} g_{i k} f_{k j}}{u_{i j}}\right]^{2}
$$

In this study, the concentration of each sample was above the detection limit and the 
240 Concentrations below the method detection limit (MDL) were calculated using Eq. (9), while 241 otherwise Eq. (10) was used.

$$
U n c=\frac{5}{6} \times M D L
$$

$$
\text { Unc }=\sqrt{(\text { Error Fraction } \times \text { concentration })^{2}+(0.5 \times M D L)^{2}}
$$

Where, Unc is uncertainty of the concentration; MDL is the method detection limit (Norris et al. 2014).

\section{Results and discussion}

\section{Selected studies}

Tab. 3 showed a summary of heavy-metal and As concentrations in the surface sediments based on the 12 papers selected. $\mathrm{Cu}, \mathrm{Zn}, \mathrm{Pb}, \mathrm{Cd}, \mathrm{Cr}$, and $\mathrm{As}$ in the surface sediment of Lake WLSH deserved special attention. In the lake surface sediments, Cd and As were relatively high, which were 6 and 4.7 times of the background values, respectively, and $\mathrm{Cu}$ was 2.3 times of the background value. $\mathrm{Zn}, \mathrm{Pb}$, and $\mathrm{Cr}$ were relatively low, ranging from 1.1 to 1.5 times of the background values and slightly higher than the values. From the perspective of coefficient of variation, $\mathrm{Cd}$ was at $82 \%, \mathrm{~Pb}$ and $\mathrm{As}$ were at $45 \%$, and other heavy metals were at $33 \%-$ 39\%. These results showed that $\mathrm{Cd}$ concentrations greatly varied in space, and the Cd contents in the sediments of Lake WLSH was highly uncertainty. Compared with the average 258 concentrations of heavy metals and As in surface sediments of Lake Taihu (Niu et al. 2020), $259 \mathrm{Cu}, \mathrm{Zn}, \mathrm{Cd}$ and $\mathrm{Cr}$ in Lake WLSH were similar to those in Taihu Lake, but the average 260 concentration of $\mathrm{Pb}$ in Lake Taihu was 1.83 times higher than that in Lake WLSH, while the average concentration of As in Lake WLSH was 3.72 times higher than that in Lake Taihu. $\mathrm{Pb}$

262 in lake sediments mainly originates from human activities such as industry and transportation 263 (Yao et al. 2008). Compared with Lake Taihu, Lake WLSH has weaker human activities, which 
264 leads to higher $\mathrm{Pb}$ concentration in surface sediments of Lake Taihu than Lake WLSH.

265 Compared with Lake Taihu, industry and agriculture around WLSH Lake basically account for $26690 \%$ of the economy (Inner Mongolia Autonomous Region Bureau of Statistics 2020). 267 Industrial wastewater (paper mills, pharmaceutical manufacturers and metal smelters) and 268 agricultural wastewater (pesticides, fertilizers) are discharged into Lake WLSH through ditches 269 (Zhang 2010; Lv 2018; Lou et al. 2020), which results in As concentrations in this lake being $270 \quad 3.72$ times higher than those in Lake Taihu.

Table 3 is here.

\section{Heavy-metal and As concentrations in overlying water}

Since the State Council approved the implementation of the "Twelfth Five-Year Plan for

Comprehensive Prevention and Control of Heavy-metal and As pollution" of China in 2011, the Inner Mongolia Autonomous Region has been listed as a key remediation area, especially bureau reported the concentration of heavy metals and As in the overlying water (Fig. 2). The maximum concentrations of $\mathrm{Cu}, \mathrm{Zn}, \mathrm{Pb}, \mathrm{Cd}, \mathrm{Cr}$ and As were 16.7, 83.6, 17.1, 0.74 and 13.41

$280 \mu \mathrm{g} \mathrm{L}^{-1}$, respectively, with large interannual variations in $\mathrm{Cd}$ and $\mathrm{Cr}$. These results indicated that a large uncertainty existed in the levels of $\mathrm{Cd}$ and $\mathrm{Cr}$ in the overlying water of the Lake WLSH.

Tab.1 shows that the concentrations of $\mathrm{Cd}$ and As in the overlying water belong to Class I standard, $\mathrm{Cu}, \mathrm{Zn}$, and $\mathrm{Cr}$ to Class II standard, and $\mathrm{Pb}$ to Class III standard. Therefore, the overlying water standard of WLSH Lake was determined to be Class III according to the environmental quality standard for surface water (GB3838-2002 of China). The WQI method can be used to deal with heavy metals observed at the same measurement location as a whole and examine the impact of these heavy metals and As on the environment through interactions 
289 (Cheng et al. 2002). Fig. 3 shows that the WQI of the lake entrance, center, and exit zones were 290 all less than 1, and were in a no polluted status from 2013 to 2017 . However, the WQI of 2017 291 was about twice as high as in previous years, the overlying water of Lake WLSH showed a 292 tendency of slight pollution, and the pollution of the lake exit zone increased significantly 293 compared with other zones. These results indicated that the overlying water of Lake WLSH 294 will be polluted by heavy metals and As if no corresponding treatment measures are taken. Figure 3 is here.

\section{Table 1 is here.}

Agriculture are the mainstay industry around the lake, and the intensity of heavy-metal and As pollution primarily depends on the soil background value (Chen et al. 2005; MarrugoNegrete et al. 2017), agricultural non-point source pollution, soil leaching intensity, and other 300 factors, whereas industrial wastewater and domestic sewage also enter the lake through the ditches (Zhang 2010). These sewages are also the most important sources of diffuse pollution in Lake WLSH (Templar et al. 2016).

\section{$I$ geo, $R I$ and $T U$ evaluation in surface sediments}

Fig. 4 shows the year of sediment sample collection and the average concentration of each heavy-metal element and As. The sediment analyses were collected from 2009 to 2017, different researchers have reported some variations in the average concentration of heavy metals and As in the surface sediments of Lake WLSH. These variations are due to the different numbers of sampling points used in different studies, leading to different results (Fan et al. 1999). For these reported mean concentrations, the maximum values for $\mathrm{Cu}, \mathrm{Zn}, \mathrm{Pb}, \mathrm{Cd}, \mathrm{Cr}$, and As were 2.9, 1.2, 1.1, 5, 0.8, and 5.6 times the background values, respectively. Among

312 them, the differences in $\mathrm{Cd}$ and As concentrations obtained by different years and researchers 313 were relatively large. 
To better reflect the heavy-metal and As pollution in the surface sediments of Lake WLSH, $I_{g e o}, R I$, and $T U$ were used to evaluate the reported element-concentration distribution characteristics. $I_{g e o}$ was calculated for the entrance, center, and exit zones of Lake WLSH using Eq. 3 (Muller 1969). The $I_{g e o}$ values for each zone of the lake are shown in Fig. 5. The highest $I_{g e o}$ values for Cd and As in the sediments of the Lake WLSH indicated moderate pollution, and those for $\mathrm{Cd}$ indicated more moderate pollution and heavy pollution in the lake exit zone. Assessment of $\mathrm{Pb}, \mathrm{Cr}$ and $\mathrm{Zn}$ in the entrance and exit zones of the lake by using $I_{g e o}$ values revealed that their $I_{g e o}$ was less than 0 , which represents a non-contaminated state in the $I_{g e o}$ grade classification. As shown in Fig. 5, the differences in $I_{g e o}$ values among the entrance, center, and exit zones of the lake were small. In comparison with the background values of heavy metals and As in Lake Taihu sediments (Niu et al. 2020), the background values of $\mathrm{Cu}$, $\mathrm{Zn}$ and $\mathrm{Cr}$ in Lake WLSH were close to those in Lake Taihu, but the large influence of human activities in Lake Taihu resulted in the background values of $\mathrm{Pb}, \mathrm{Cd}$ and $\mathrm{As}$ being 1.55, 2.52 and 1.6 times higher than those in Lake WLSH, respectively. The geoaccumulation indices showed that Cd and As are the most important pollutant of Lake WLSH, while Lake Taihu 330 showed that $\mathrm{Cd}$ is the most important pollutant (Niu et al. 2020). The main source of As heavy metal is the substantial use of pesticides and fertilizers in the upstream of HID (Lou et al. 2020), 332 and the main source of $\mathrm{Cd}$ is the upstream printing and dyeing, papermaking, and other factory discharged sewage (Liu et al. 2015). Agriculture and industry play pivotal roles in heavy-metal 334 and As contamination around the Lake WLSH. Therefore, wastewater discharges from 335 industrial and agriculture sources should be treated appropriately (Feng et al. 2005; Xu et al. 2009; Zhang 2010; Zhao 2013; Liang 2019). 

by using Eqs. 2 and 3 (Hakanson 1980), as shown in Fig. 6. The $E_{r}^{i}$ values of Cd in the three zones of the lake were greater than 160, indicating high risk; and those of the remaining heavy metals and As were less than 40, indicating low risk (Fig. 6a). The high $\mathrm{Cd} I_{g e o}$ values also caused high RIs. Cd contributed $75.2 \%$ of the potential ecological risk (Fig. 6b), and $\mathrm{Cd}$ potential ecological risk in the exit zone is slightly higher than in the other two zones. Cd was also the main contributor to the potential ecological risk in the sediments of Lake Taihu, and it contributed $71 \%$ of the potential ecological risk (Niu et al. 2020). Heavy metals and As continually accumulate in plants and fish through the food chain and causes many fatal diseases (e.g., loss of intelligence quotient and nephrotic syndrome) when consumed by humans

348 (Hildebrand et al. 1980; Koomans et al. 1985). Many reports have shown that heavy metals and

349 As have a negative impact on microbial-community diversity (e.g., the biomass of algae 350 decreases with increased Cd concentration) (Gupta and Rastogi 2008; Deng et al. 2015). 351 However, the indirect ecological risks associated with changes in microbial communities are 352 difficult to predict.

\section{Figure 6 is here.}

Two sets of sediment quality guidelines (SQGs), the threshold effect level (TEL)/probable effect level (PEL) and the effect range low (ERL)/effect range medium (ERM), were adopted for screening the environmental risk due to heavy metals and As in the sediments of Lake WLSH (MacDonald et al. 2000). ERLs and TELs are categorized as low range values and refer 358 to concentrations below which adverse effects on sediment-dwelling fauna occur infrequently.

359 In contrast, PELs and ERMs are purported to allow the identification of pollutant concentrations 360 above which adverse effects on sediment-dwelling organisms occur frequently (MacDonald et al. 2000). In this paper, comparing the heavy metals and As concentrations in Lake WLSH 362 sediments with ERL and ERM, the maximum concentrations of As were found to be higher 
than ERM, the maximum concentrations of $\mathrm{Cu}$ and $\mathrm{Cd}$ were lower than ERL, and the maximum concentrations of $\mathrm{Zn}, \mathrm{Pb}$, and $\mathrm{Cr}$ were distributed between ERL and ERM. Compared with TEL and PEL, the maximum concentrations of $\mathrm{Pb}, \mathrm{Cr}$ and $\mathrm{As}$ were higher than the PEL and the maximum concentrations of $\mathrm{Cu}, \mathrm{Zn}$ and $\mathrm{Cd}$ were between the TEL and the PEL. In this paper, comparing the heavy metals and As concentrations in Lake WLSH sediments with ERL and ERM, the maximum concentrations of As were found to be higher than ERM, the maximum concentrations of $\mathrm{Cu}$ and $\mathrm{Cd}$ were lower than ERL, and the maximum concentrations of $\mathrm{Zn}, \mathrm{Pb}$, and $\mathrm{Cr}$ were distributed between ERL and ERM. Compared with TEL and PEL, the maximum concentrations of $\mathrm{Pb}, \mathrm{Cr}$ and As were higher than the PEL and the maximum concentrations of $\mathrm{Cu}, \mathrm{Zn}$ and $\mathrm{Cd}$ were between the TEL and the PEL. Toxicity characteristics of heavy metals and As in the sediments of Lake WLSH were calculated by Eq. 6 (Pedersen et al. 1998). The statistical results are shown in Fig. 7. The risk profile of the sediment $T U$ 's and $\Sigma T U$ 's in the lake showed that the $\Sigma T U$ 's in the entrance, center, and exit zones were 2.96, 2.78, and 2.75, respectively, indicating low toxicity level, but the lake entrance zone was more polluted. And As of $T U$ 's were all higher than heavy metals $(\mathrm{Cu}, \mathrm{Zn}, \mathrm{Pb}, \mathrm{Cd}$, and $\mathrm{Cr})$ in the three zones of the 378 lake, were $0.99,0.89$, and 0.75 , respectively, indicating low toxicity level. The $T U$ 's of the 379 heavy metals and As were also less than 4, indicating low toxicity grade (Fig. 7a). As metal contributed $33.44 \%, 32.29 \%$, and $27.26 \%$ of $T U$ 's in the entrance, center, and exit zones of the lake, respectively (Fig. 7b). The toxicity of heavy metals and As in the sediments of Lake WLSH was As, with a total toxicity contribution of about $30.98 \%$; while the toxicity of heavy metals in the sediments of Lake Taihu was $\mathrm{Pb}$, with a total toxicity contribution of about $32 \%$

384 (Niu et al. 2020). Arsenic in sediments is generally present mainly in the low solubility form, 385 bound primarily to iron oxides and present in the residual phase, and will be released into the overlying water as the sediment conditions (e.g., temperature, $\mathrm{pH}$, etc.) change (Nikolaidis et 
al. 2004; Arain et al. 2009). Therefore, the sources of pollution in Lake WLSH need to be

388 effectively identified and appropriate control measures should be developed.

Figure 7 is here.

\section{Appraisal of heavymetals and As apportioning sources}

By running the model several times and adjusting the number of factors, the best

simulation results were obtained when the seed number of the four factors was randomly started

at 32 , the rotation factor $F_{\text {peak }}$ was set to -0.5 , and 20 iterations were performed. The residual errors showed a normal distribution between -3 and 3 . The fit coefficient $\left(R^{2}\right)$ between measured and simulated element concentrations was higher than 0.8 , and the difference between $\mathrm{Q}$ and theoretical Q was less than 10\%, indicating that the model analysis met the requirements (Norris

et al. 2014). PMF model was applied to study the possible sources of heavy metals and As emissions from the surface sediments of Lake WLSH, and the total contribution rate was explained in the Tab. 4.

Factor 1 explained a very large proportion (43.2\%) of the contributions of different sources of heavy metals and As to the heavy metal and As concentrations in the sediment of Lake WLSH and had high factor loadings for $\mathrm{Cu}, \mathrm{Zn}, \mathrm{Pb}$ and As. These metals and As are usually discharged by the papermaking, printing, and steel manufacturing industries, which have played the important roles in the economic development of the Lake WLSH Basin (Inner Mongolia Autonomous Region Bureau of Statistics 2020). Zn, Pb and As made similar contributions to Factor 4, and this was similar to the features of complex industrial sources (Yang et al. 2018; Niu et al. 2020). Hence, Factor 1 was associated with industrial sources.

Factor 2 explains only $4.2 \%$ of the contribution of different sources of heavy metals and 411 arsenic to heavy metal and arsenic concentrations in the sediment of Lake WLSH, and factor loadings are low $(<10 \%)$ for all heavy metals and 0 for As. In geochemical baseline studies, 
natural sources of heavy metals and As contribute to background values of concentrations in

414 local soils and sediments. Anthropogenic sources contributed much more heavy metals and As

415 to lake sediments than natural sources (Niu et al. 2020), and non-anthropogenic sources

416 contributed slightly to heavy metal and As concentrations in the sediment of Lake WLSH.

417 Hence, factor 2 is related to natural sources.

418 Factor 3 explained only $10.0 \%$ of the contributions of different sources of heavy metals

419 and As to the heavy metal and As concentrations in the sediment of Lake WLSH. Heavy metals

420 and As are carried by atmospheric particulate matter and eventually enter lake water bodies by

421 the way of sedimentation, which can cause heavy-metal and As pollutions of lakes (Larsen

422 1993; Steinnes et al. 1993; Li et al. 2021). Due to the rapid development of industry and

423 transportation around lake, the use of fossil fuels (coal, gasoline, and diesel) has led to

424 significant increases in local atmospheric heavy metal and As levels (Ouellet et al. 1983; Rose

425 et al. 1998). Yin et al. (2014) demonstrated that atmospheric deposition of heavy metals and As

426 into the Lake WLSH is another important source of heavy metal and As pollution in addition

427 to the drainage ditches input to the lake. Hence, Factor 4 was associated with atmospheric 428 deposition sources.

429 Factor 4 explained $42.6 \%$ of the contributions of different sources of heavy metals and As

430 to the heavy-metal and As concentrations in the sediment of Lake WLSH and had high factor

431 loadings for $\mathrm{Zn}, \mathrm{Pb}, \mathrm{Cd}, \mathrm{Cr}$ and As. These heavy metals and As are indicators of agricultural

432 fertilizer and pesticide use in the Lake WLSH Basin (Skordas and Kelepertsis 2005; Shi et al.

433 2020b). Lake WLSH was located at the end of HID and was responsible for the discharge of

434 agricultural sewage, which carried a large amount of fertilizer and pesticide (Feng et al. 2005;

$435 \mathrm{Xu}$ et al. 2009; Liu et al. 2015). Fertilizer utilization in the region less than $30 \%$, and all

436 farmland wastewater was collected through farmland drainage channels into the Lake WLSH 
437 (Lou et al. 2020), which increased the heavy metal and As pollution of Lake WLSH. Hence,

438 Factor 4 was associated with agricultural sources.

\section{Conclusions}

Heavy-metal and As pollutions in the Lake WLSH were systematically analyzed based on

442 the heavy-metal and As concentrations in the surface sediments, which were found in studies 443 from 2009 to 2017. Several conclusions were drawn. The water quality index of the overlying 444 water showed a tendency of slight pollution in the lake from 2013 to 2017. Heavy metals $(\mathrm{Cu}$, $445 \mathrm{Zn}, \mathrm{Pb}, \mathrm{Cd}$, and $\mathrm{Cr}$ ) and As were the most concern in the surface sediment of the lake between 2009 and 2017. In terms of cumulative contamination and potential ecological risk, the lake

447 sediment was most heavily contaminated with $\mathrm{Cd}$, accounting for $75.2 \%$ of the potential 448 ecological risk (assessed using $R I$ ). Within a toxicity-risk control perspective, although As is at 449 a low toxicity level, its toxicity-risk contribution is higher than that of other metals 450 (approximately 31\%). The PMF model indicated that heavy metals and As in Lake WLSH 451 sediment have mainly been supplied by industrial and agricultural resources, which have 452 contributed $43.2 \%$ and $42.6 \%$ of the total heavy metal and As concentrations, respectively. 453 Natural sources and atmospheric deposition sources have contributed $4.2 \%$ and $10.0 \%$, respectively, of the total heavy metal and As concentrations. In order to prevent heavy metals and As in drainage ditch sediment being transported into Lake WLSH because of human activities such as lake ecological water replenishment, the wastewater discharges from

457 industrial and agricultural sources also need to be controlled and monitored more effectively 458 than is currently the case. All these results can provide comprehensive and quantitative 459 reference data for heavy metal and As pollution in Lake WLSH. 
462 Not applicable.

463

464 Consent to participate

465 Not applicable.

466

467 Consent for publication

468 Not applicable.

469

470

Availability of data and materials

471

All data generated or analysed during this study are included in this published article and its supplementary information files.

473

474

Competing interests

475

The authors declare that they have no competing interests.

476

477

\section{Funding}

This research was financially supported by the National Major Science and Technology

Projects "High Efficient Water Saving and Non-Point Source Pollution Prevention and Control in the Area of 'One lake, Two seas' of Inner Mongolia" of China (No. 2019YFC0409203).

\section{Authors Contributions}

Huaijie He was responsible for gathering literature, processing data, and writing the first draft. Ling Liu was responsible for providing fund support, processing data, and revising the manuscript. Wenming Yan was responsible for gathering literature and processing data.

\section{Acknowledgements}

488 This research was financially supported by the National Major Science and Technology 489 Projects "High Efficient Water Saving and Non-Point Source Pollution Prevention and Control 
in the Area of 'One lake, Two seas' of Inner Mongolia" of China (No. 2019YFC0409203).

Thanks to the anonymous reviewers for their valuable comments on this paper.

492

493

494

495

496

497

498

499

500

501

502

503

504

505

506

507

508

509

510

511

\section{References}

Adams WJ, Green AS, Ahlf W, Brown SS, Burton GA, Chadwick B, Crane M, Gouget R, Ho KT, Hogstand C, 2005. Using sediment assessment tools and a weight of evidence approach. Use Sediment Qual. Guidel. Relat. Tools Assess. Contam. Sediments Soc. Environ. Toxicol. Chem. Pensacola FL USA 163-225.

Allen Burton G, 2018. Breaking from tradition: establishing more realistic sediment quality guidelines. Environ. Sci. Pollut. Res. 25:3047-3052.

Ali MM, Ali ML, Islam MdS, Rahman MdZ, 2016. Preliminary assessment of heavy metals in water and sediment of Karnaphuli River, Bangladesh. Environ. Nanotechnol. Monit. Manag. 5:27-35.

Bai J, Cui B, Chen B, Zhang K, Deng W, Gao H, Xiao R, 2011. Spatial distribution and ecological risk assessment of heavy metals in surface sediments from a typical plateau lake wetland, China. Ecol. Model. 222:301-306.

Benateau S, Gaudard A, Stamm C, Altermatt F, 2019. Climate change and freshwater ecosystems: impacts on water quality and ecological status. Fed. Off. Environ. FOEN Eawag.

Bewers JM, 1995. The declining influence of science on marine environmental policy. Chem. Ecol. 10:9-23.

Chen T, Zheng Y, Lei M, Huang Z, Wu H, Chen H, Fan K, Yu K, Wu X, Tian Q, 2005. Assessment of heavy metal pollution in surface soils of urban parks in Beijing, China. Chemosphere 60:542-551. 
Cheng S, Grosse W, Karrenbrock F, Thoennessen M, 2002. Efficiency of constructed wetlands in decontamination of water polluted by heavy metals. Ecol. Eng. 18:317-325.

Deng L, Zeng G, Fan C, Lu L, Chen X, Chen M, Wu H, He X, He Y, 2015. Response of rhizosphere microbial community structure and diversity to heavy metal co-pollution in arable soil. Appl. Microbiol. Biotechnol. 99:8259-8269.

Fan X, Thompson B, Wang L, 1999. Effects of sample size, estimation methods, and model specification on structural equation modeling fit indexes. Struct. Equ. Model. Multidiscip. J. 6:56-83.

Feng Z, Wang X, Feng Z, 2005. Soil N and salinity leaching after the autumn irrigation and its impact on groundwater in Hetao Irrigation District, China. Agric. Water Manag. 71:131-143.

Förstner U, Prosi F, 1979. Heavy Metal Pollution in Freshwater Ecosystems. Biol. Asp. Freshw. Pollut. 129-161.

Fu J, Hu X, Tao X, Yu H, Zhang X, 2013. Risk and toxicity assessments of heavy metals in sediments and fishes from the Yangtze River and Taihu Lake, China. Chemosphere 93:1887-1895.

Gao H, Wang X, Zhang Q, Li S, 2007. Characteristics of soil background value in Hetao area, Inner Mongolia. Geol. Resour. 16:209-212. (in Chinese with English abstract)

Gao H, Yan C, Liu Q, Ding W, Chen B, Li Z, 2019. Effects of plastic mulching and plastic residue on agricultural production: A meta-analysis. Sci. Total Environ. 651:484-492.

Gupta VK, Rastogi A, 2008. Equilibrium and kinetic modelling of cadmium(II) biosorption by nonliving algal biomass Oedogonium sp. from aqueous phase. J. Hazard. Mater. 153:759-766.

Hakanson L, 1980. An ecological risk index for aquatic pollution control.a sedimentological approach. Water Res. 14:975-1001. 
Hernandez AV, Marti KM, Roman YM, 2020. Meta-Analysis. CHEST 158:S97-S102.

540 Hildebrand SG, Strand RH, Huckabee JW, 1980. Mercury Accumulation in Fish and Invertebrates of the North Fork Holston River, Virginia and Tennessee. J. Environ. Qual. 9:393-400.

Hou D, He J, Lü C, Ren L, Fan Q, Wang J, Xie Z, 2013. Distribution characteristics and potential ecological risk assessment of heavy metals $(\mathrm{Cu}, \mathrm{Pb}, \mathrm{Zn}, \mathrm{Cd})$ in water and sediments from Lake Dalinouer, China. Ecotoxicol. Environ. Saf. 93:135-144.

Huang Y, Wang L, Wang W, Li T, He Z, Yang X, 2019. Current status of agricultural soil pollution by heavy metals in China: A meta-analysis. Sci. Total Environ. 651:30343042.

Inner Mongolia Autonomous Region Bureau of Statistics, 2020. INNER MONGOLIA STATISTICAL YEARBOOK. China Statistics Press.

Jiao X, Dong Z, Kang S, Li Y, Jiang C, Rostami M, 2021. New insights into heavy metal elements deposition in the snowpacks of mountain glaciers in the eastern Tibetan Plateau. Ecotoxicol. Environ. Saf. 207:111228.

Ke X, Gui S, Huang H, Zhang H, Wang C, Guo W, 2017. Ecological risk assessment and source identification for heavy metals in surface sediment from the Liaohe River protected area, China. Chemosphere 175:473-481.

Koomans HA, Kortlandt W, Geers AB, Dorhout Mees EJ, 1985. Lowered protein content of tissue fluid in patients with the nephrotic syndrome: observations during disease and recovery. Nephron 40:391-395.

Kumar V, Parihar RD, Sharma A, Bakshi P, Singh Sidhu GP, Bali AS, Karaouzas I, Bhardwaj R, Thukral AK, Gyasi-Agyei Y, Rodrigo-Comino J, 2019. Global evaluation of heavy metal content in surface water bodies: A meta-analysis using heavy metal pollution indices and multivariate statistical analyses. Chemosphere 236:124364. 
Larsen VJ, 1983. The significance of atmospheric deposition of heavy metals in four Danish lakes. Sci. Total Environ. 30:111-127.

Li H, Shi A, Li M, Zhang X, 2013. Effect of pH, Temperature, Dissolved Oxygen, and Flow Rate of Overlying Water on Heavy Metals Release from Storm Sewer Sediments. J. Chem. 2013:e434012.

Li Y, Zhou S, Jia Z, Liu K, Wang G, 2021. Temporal and spatial distributions and sources of heavy metals in atmospheric deposition in western Taihu Lake, China. Environ. Pollut. 117465.

Liang P, 2019. Study on distribution characteristics and Environmental risks of Heavy metals in Suhai Lake, Wuliang, Inner Mongolia. (Master). Minzu University of China. (in Chinese with English abstract)

Lin Q, Liu E, Zhang E, Li K, Shen J, 2016. Spatial distribution, contamination and ecological risk assessment of heavy metals in surface sediments of Erhai Lake, a large eutrophic plateau lake in southwest China. CATENA 145:193-203.

Liu J, Sun S, Wu P, Wang Y, Zhao X, 2015. Evaluation of crop production, trade, and consumption from the perspective of water resources: A case study of the Hetao irrigation district, China, for 1960-2010. Sci. Total Environ. 505:1174-1181.

Liu W, Guo Z, Jiang B, Lu F, Wang H, Wang D, Zhang M, Cui L, 2020. Improving wetland ecosystem health in China. Ecol. Indic. 113:106184.

Lou S, Yang S, Liu R, Liu D, 2020. Optimizing Nitrogen and Phosphorus Fertilization to Improve Sunflower Yield in Hetao Irrigation Districtt. Journal of Irrigation and Drainage. 39:35-43. (in Chinese with English abstract)

Lv J, 2018. Release Mechanism of Heavy Metals from Sediments in Wuliangsuhai under Environmental Changes. (Master). Inner Mongolia Agricultural University. (in Chinese with English abstract) 
MacDonald DD, Ingersoll CG, Berger TA, 2000. Development and Evaluation of ConsensusBased Sediment Quality Guidelines for Freshwater Ecosystems. Arch. Environ. Contam. Toxicol. 39:20-31.

MacDonald DD, Ingersoll CG, 2002. A Guidance Manual to Support the Assessment of Contaminated Sediments in Freshwater Ecosystems. US Environ. Prot. Agency Gt. Lakes Natl. Program Off.

Marrugo-Negrete J, Pinedo-Hernández J, Díez S, 2017. Assessment of heavy metal pollution, spatial distribution and origin in agricultural soils along the Sinú River Basin, Colombia. Environ. Res. 154:380-388.

Muller G, 1969. Index of Geoaccumulation in Sediments of the Rhine River. GeoJournal, $2: 108-118$.

Nazari-Sharabian M, Ahmad S, Karakouzian M, 2018. Climate Change and Eutrophication: A Short Review. Eng. Technol. Appl. Sci. Res. 8:6.

Nikolaidis NP, Dobbs GM, Chen J, Lackovic JA, 2004. Arsenic mobility in contaminated lake sediments. Environ. Pollut. 129:479-487.

Niu Y, Jiang X, Wang K, Xia J, Jiao W, Niu Y, Yu H, 2020. Meta analysis of heavy metal pollution and sources in surface sediments of Lake Taihu, China. Sci. Total Environ. 700:134509.

Niu Y, Jiao W, Yu H, Niu Y, Pang Y, Xu X, Guo X, 2015. Spatial Evaluation of Heavy Metals Concentrations in the Surface Sediment of Taihu Lake. Int. J. Environ. Res. Public. Health 12:15028-15039.

Norris G, Duvall R, Brown S, Bai S, 2014. Epa positive matrix factorization (pmf) 5.0 fundamentals and user guide prepared for the us environmental protection agency office of research and development, Washington, DC. 
613 Ouellet, M., \& Jones, H. G. (1983). Historical changes in acid precipitation and heavy metals

614

615

616

617

618

619

620

621

622

623

624

625

626

627

628

629

630

631

632

633

634

635 deposition originating from fossil fuel combustion in eastern North America as revealed by lake sediment geochemistry. Water Science and Technology, 15(12), 115-130.

Paatero P, 1997. Least squares formulation of robust non-negative factor analysis. Chemom. Intell. Lab. Syst. 37:23-35.

Pedersen F, Bjørnestad E, Andersen HV, Kjølholt J, Poll C, 1998. Characterization of sediments from Copenhagen Harbour by use of biotests. Water Sci. Technol. 37:233-240.

Rai PK, 2008. Heavy Metal Pollution in Aquatic Ecosystems and its Phytoremediation using Wetland Plants: An ecosustainable approach. Int. J. Phytoremediation 10:133-160.

Rose NL, Appleby PG, Boyle JF, Mackay AW, Flower RJ, 1998. The spatial and temporal distribution of fossil-fuel dervied pollutants in the sediment record of Lake Baikal, east Siberia. J. Paleolimnol. 20:151-162.

Shao D, Zhan Y, Zhou W, Zhu L, 2016. Current status and temporal trend of heavy metals in farmland soil of the Yangtze River Delta Region: Field survey and meta-analysis. Environ. Pollut. 219:329-336.

Shi R, Zhao J, Shi W, Song S, Wang C, 2020a. Comprehensive Assessment of Water Quality and Pollution Source Apportionment in Wuliangsuhai Lake, Inner Mongolia, China. Int. J. Environ. Res. Public. Health 17:5054.

Shi W, Liu Y, Li J, Zhang H, Shi R, Chen J, Li H, 2020b. Distribution pattern of antibiotic resistance genes and bacterial community in agricultural soil samples of Wuliangsuhai watershed. China. Agric. Ecosyst. Environ. 295:106884.

Simpson RJS, Pearson K, 1904. Report on certain enteric fever inoculation statistics. Br. Med. J. 1904:1243-1246. 
636 Skordas K, Kelepertsis A, 2005. Soil contamination by toxic metals in the cultivated region of Agia, Thessaly, Greece. Identification of sources of contamination. Environ. Geol. $48: 615-624$.

Steinnes, E., \& Henriksen, A. (1993). Metals in small Norwegian lakes: Relation to atmospheric deposition of pollutants. Water, Air, and Soil Pollution, 71(1), 167-174.

Templar HA, Dila DK, Bootsma MJ, Corsi SR, McLellan SL, 2016. Quantification of humanassociated fecal indicators reveal sewage from urban watersheds as a source of pollution to Lake Michigan. Water Res. 100:556-567.

Wang S, Meng W, Jin X, Zheng B, Zhang L, Xi H, 2015. Ecological security problems of the major key lakes in China. Environ. Earth Sci. 74:3825-3837.

Wang X, Huang Z, Su M, Li S, Wang Z, Zhao S, Zhang Q, 2007. Characteristics of Reference and Background Values of Soils in Hetao Area. Rock and Mineral Analysis. 26:287292. (in Chinese with English abstract)

Wen Y, Shang S, Rahman KU, Xia Y, Ren D, 2020. A semi-distributed drainage model for monthly drainage water and salinity simulation in a large irrigation district in arid region. Agric. Water Manag. 230:105962.

Xu X, Huang G, Qu Z, 2009. Integrating MODFLOW and GIS technologies for assessing impacts of irrigation management and groundwater use in the Hetao Irrigation District, Yellow River basin. Sci. China Ser. E Technol. Sci. 52:3257. 
Yan X, Liu M, Zhong J, Guo J, Wu W, 2018. How Human Activities Affect Heavy Metal Contamination of Soil and Sediment in a Long-Term Reclaimed Area of the Liaohe River Delta, North China. Sustainability 10:338.

Yang H, Yu R, Guo R, Hao Y, Zhang Y, 2014. Assessment of Eutrophication in Wuliangsuhai Lake. Adv. Mater. Res. 955-959:1098-1102.

Yang Q, Li Z, Lu X, Duan Q, Huang L, Bi J, 2018. A review of soil heavy metal pollution from industrial and agricultural regions in China: Pollution and risk assessment. Sci. Total Environ. 642:690-700.

Yang X, Wu X, Hao H, He Z, 2008. Mechanisms and assessment of water eutrophication. J. Zhejiang Univ. Sci. B 9:197-209. (in Chinese with English abstract)

Yao S, Xue B, Zhu Y, Xia W, Li S, 2008. Sediment lead pollution records from lakes at the middle and lower reaches of Changjiang river basin: case study in Honghu, Guchenghu, and Taihu lakes. Quat. Sci. 28:659-666. (in Chinese with English abstract)

Yi Y, Yang Z, Zhang S, 2011. Ecological risk assessment of heavy metals in sediment and human health risk assessment of heavy metals in fishes in the middle and lower reaches of the Yangtze River basin. Environ. Pollut. 159:2575-2585.

Yin, L. L., Jia, K. L., Shi, X. H., Zhao, S. N., Yang, F., \& Wu, Y. (2014). Atmospheric deposition characteristics and fluxes of heavy metals in Lake Ulansuhai. J Lake Sci, 26, 931-938. (in Chinese with English abstract)

Yu R, Liu T, Shang M, 2012. The Environment Variation and Analysis of Wuliangsuhai Wetland in Inner Mongolia Autonomous Region. Adv. Mater. Res. 518-523:13481354.

Zedler JB, Kercher S, 2005. WETLAND RESOURCES: Status, Trends, Ecosystem Services, and Restorability. Annu. Rev. Environ. Resour. 30:39-74. 
Zhang X, 2010. Experimental study on the nutrient release and pollution characteristics of the sediment in Wuliangsuhai Lake. (Master). Inner Mongolia Agricultural University. (in Chinese with English abstract)

Zhang Y, Jia Y, Jiao S, Zeng Q, Feng D, Guo Y, Lei G, 2012. Wuliangsuhai Wetlands: A Critical Habitat for Migratory Water Birds. J. Resour. Ecol. 3:316-323.

Zhang Z, Juying L, Mamat Z, QingFu Y, 2016. Sources identification and pollution evaluation of heavy metals in the surface sediments of Bortala River, Northwest China. Ecotoxicol. Environ. Saf. 126:94-101.

Zhao S, 2013. A study of nutrient elements and heavy metal pollitants and their environmental effects of the water and bed sediments of the Wuliangsuhai Lake in Inner Mengolia. (Doctor). China University of Geosciences (Beijing). (in Chinese with English abstract) Zhou T, Li L, Zhang X, Zheng J, Zheng J, Joseph S, Pan G, 2016. Changes in organic carbon and nitrogen in soil with metal pollution by $\mathrm{Cd}, \mathrm{Cu}, \mathrm{Pb}$ and $\mathrm{Zn}$ : a meta-analysis. Eur. J. Soil Sci. 67:237-246. 


\section{Tables}

699 Table. 1 Statistical description of heavy-metal and As guideline values for overlying water

700 and water quality grade.

\begin{tabular}{ccccccc}
\hline \multirow{2}{*}{ Category } & \multicolumn{6}{c}{ Overlying water heavy-metal and As concentrations $\left(\mu \mathrm{g} \mathrm{L}^{-1}\right)$} \\
\cline { 2 - 7 } & $\mathrm{Cu}$ & $\mathrm{Zn}$ & $\mathrm{Pb}$ & $\mathrm{Cd}$ & $\mathrm{Cr}$ & $\mathrm{As}$ \\
\hline Minimum & 0.19 & 10.16 & 0.15 & 0.07 & 0.06 & 0.69 \\
Maximum & 16.71 & 83.61 & 17.10 & 0.75 & 22.33 & 13.41 \\
Mean & 6.33 & 32.66 & 3.35 & 0.17 & 5.64 & 5.74 \\
S.D. & 3.60 & 14.44 & 2.24 & 0.14 & 4.50 & 3.08 \\
CV (\%) & $57 \%$ & $44 \%$ & $67 \%$ & $84 \%$ & $80 \%$ & $54 \%$ \\
Water quality grade $^{\mathrm{a}}$ & $\mathrm{II}$ & $\mathrm{II}$ & $\mathrm{III}$ & $\mathrm{I}$ & $\mathrm{II}$ & $\mathrm{I}$
\end{tabular}

701 S.D.: standard deviation; CV: coefficient of variation.

702 a Water-quality grade: The maximum concentrations of various metals in the overlying water of Lake Wuliangsuhai were taken, and the water-quality was rated with reference to the Surface Water Environmental Quality Standard 704 GB3838-2002 of China. 
705 Table. 2 Terminology used to describe the potential ecological risk (i.e., $E_{r}^{i}, R I$, and $I_{\text {geo }}$ ).

\begin{tabular}{|c|c|c|c|c|c|}
\hline$E_{r}^{i}$ value & $\begin{array}{l}\text { Grades of } \\
\text { ecological risk of a } \\
\text { single metal }\end{array}$ & $R I$ value & $\begin{array}{l}\text { Grades of } \\
\text { potential } \\
\text { ecological risk } \\
\text { to the } \\
\text { environment }\end{array}$ & $I_{\text {geo }}$ & $\begin{array}{l}\text { Geoaccumulation-index } \\
\text { grades }\end{array}$ \\
\hline$E_{r}^{i}<40$ & Low risk & $R I<150$ & Low risk & $I_{\mathrm{geo}} \leq 0$ & Uncontaminated \\
\hline $40 \leq E_{r}^{i}<80$ & Moderate risk & $150 \leq R I<300$ & Moderate risk & $0<I_{\mathrm{geo}}<1$ & $\begin{array}{l}\text { Uncontaminated to } \\
\text { moderately contaminated }\end{array}$ \\
\hline $80 \leq E_{r}^{i}<160$ & Considerable risk & $300 \leq R I<600$ & High risk & $1<I_{\text {geo }}<2$ & Moderately contaminated \\
\hline $160 \leq E_{r}^{i}<320$ & High risk & $R I \geq 600$ & Higher risk & $2<I_{\text {geo }}<3$ & $\begin{array}{l}\text { Moderately to heavily } \\
\text { contaminated }\end{array}$ \\
\hline$E_{r}^{i} \geq 320$ & Extremely high risk & & & $3<I_{\text {geo }}<4$ & Heavily contaminated \\
\hline
\end{tabular}


Table. 3 Statistical description of heavy-metal and As guideline values for sediment in selected publications, 708 heavy-metal and As background values.

\begin{tabular}{ccccccc}
\hline \multirow{2}{*}{ Category } & \multicolumn{6}{c}{ Sediment heavy-metal concentrations $\left(\mathrm{mg} \mathrm{kg}^{-1}\right)$} \\
\cline { 2 - 7 } & $\mathrm{Cu}$ & $\mathrm{Zn}$ & $\mathrm{Pb}$ & $\mathrm{Cd}$ & $\mathrm{Cr}$ & $\mathrm{As}$ \\
\hline Minimum & 13.40 & 32.37 & 1.71 & 0.07 & 24.14 & 3 \\
Maximum & 61.77 & 217.51 & 49.22 & 2.1 & 112.59 & 89.9 \\
Mean & 31.79 & 83.65 & 19.38 & 0.3 & 43.39 & 29 \\
S.D. & 11.41 & 34.13 & 9.38 & 0.26 & 20.55 & 14.04 \\
CV (\%) & $36 \%$ & $41 \%$ & $48 \%$ & $87 \%$ & $47 \%$ & $48 \%$ \\
TEL & 35.7 & 123 & 18 & 0.596 & 37.3 & 5.9 \\
PEL & 197 & 315 & 36 & 3.53 & 90 & 17 \\
PEC $^{\mathrm{a}}$ & 149 & 459 & 128 & 4.98 & 111 & 33 \\
ERL $^{\mathrm{a}}$ & 70 & 120 & 35 & 5 & 80 & 33 \\
ERM $^{\mathrm{a}}$ & 390 & 270 & 110 & 9 & 145 & 85 \\
Background value & 13.92 & 56.61 & 16.85 & 0.05 & 39.78 & 6.12
\end{tabular}

S.D.: standard deviation; CV: coefficient of variation.

710 a TEL: threshold effect level; PEL: probable effect level, PEC: probable effect concentration (MacDonald et al., 711 2000; MacDonald and Ingersoll, 2002); ERL: effects range low; ERM: effects range median (MacDonald et al., 712 2000; MacDonald and Ingersoll, 2002).

$713{ }^{\mathrm{b}}$ The background values of the surface soil in the Loop provided in the Geological Survey of National Land

714 Resources-Inner Mongolia Loop Agricultural and Economic Zone Eco-geochemical Investigation Project

715 (200414200005) were used as the background values of the surface sediments of Lake Wuliangsuhai (Gao et al., 716 2007; Wang et al., 2007). 
717 Table. 4 Factor analysis results of PMF model.

\begin{tabular}{ccccc}
\hline Element & Factor.1 (\%) & Factor.2 (\%) & Factor.3 (\%) & Factor.4 (\%) \\
\hline $\mathrm{Cu}$ & 72.7 & 5.6 & 0 & 21.7 \\
$\mathrm{Zn}$ & 40.6 & 6.2 & 17.3 & 35.9 \\
$\mathrm{~Pb}$ & 48.3 & 1.8 & 10.9 & 39 \\
$\mathrm{Cd}$ & 26.3 & 6.7 & 3.3 & 63.7 \\
$\mathrm{Cr}$ & 26.7 & 5.0 & 21.4 & 46.9 \\
$\mathrm{As}$ & 45.1 & 0 & 6.8 & 48.1 \\
Total Contribution Rate & 43.2 & 4.2 & 10.0 & 42.6 \\
\hline
\end{tabular}


(a)

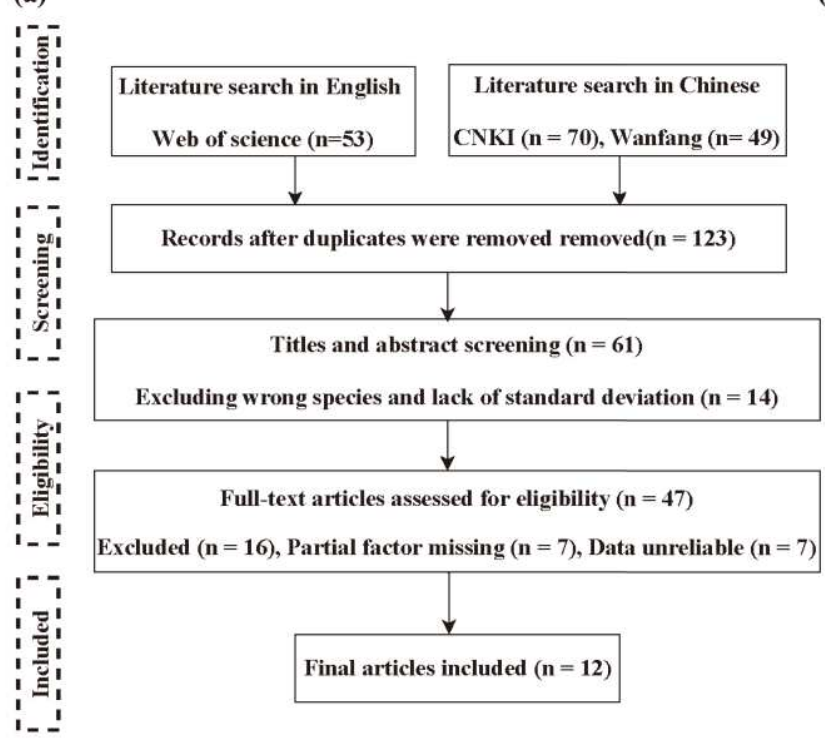

720

721 Fig. 1 Literature selection and distribution of sample points in the experimental area in

722 literature. (a) Processes of selection of literature and screening of qualified literature in 723 electronic databases (eligible literature $n=12$; Supplementary Material shows the detailed 724 bibliography). (b) Lake Wuliangsuhai is located in an arid agroecosystem in Inner Mongolia

725 Autonomous Region, located in the North of China. In this article, the lakes were divided into 726 entrance, center, and exit zones and labeled with the number of samples obtained from 727 literature.

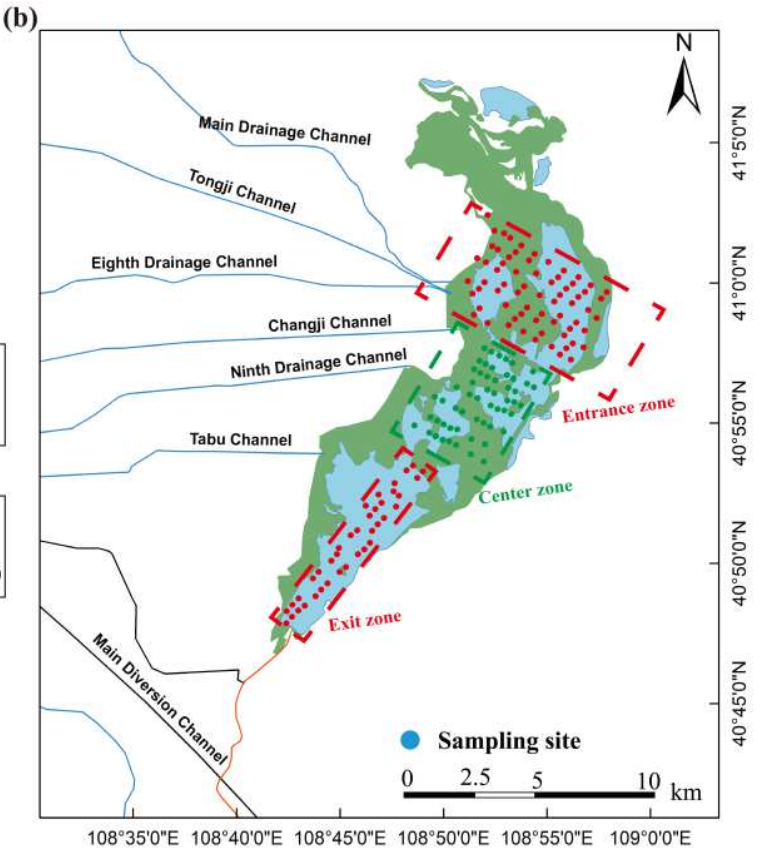



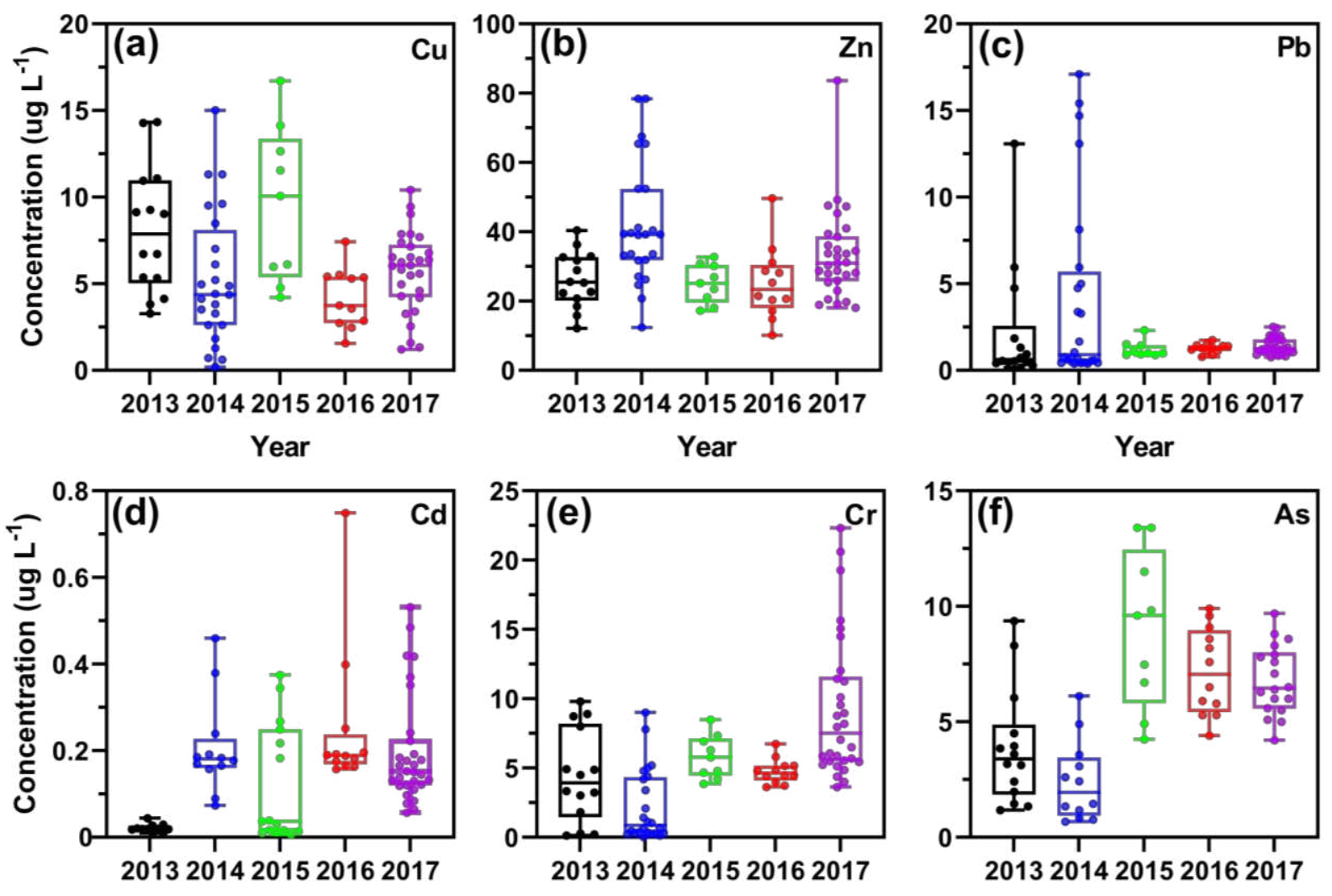

728

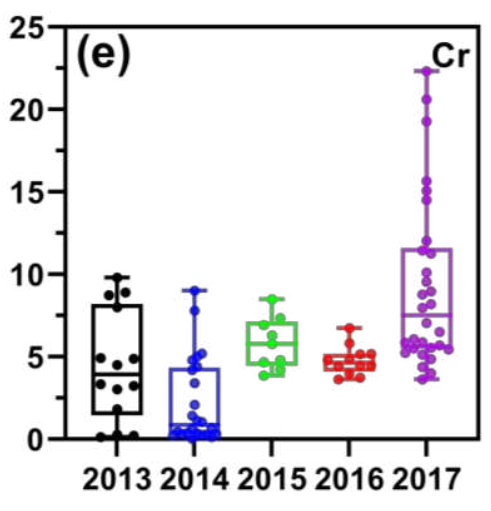

Year

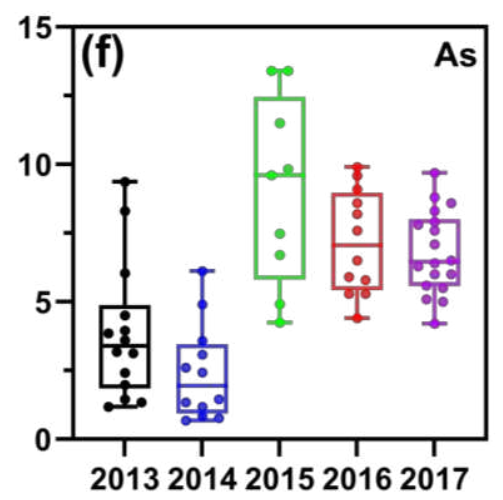

Year

729 Fig. 2 Distribution of heavy-metal and As concentrations in the overlying water of Lake

730 Wuliangsuhai within 2013-2017 (unit: $\mu \mathrm{g} \mathrm{L}^{-1}$ ). (Data from Lake WLSH administration bureau) 


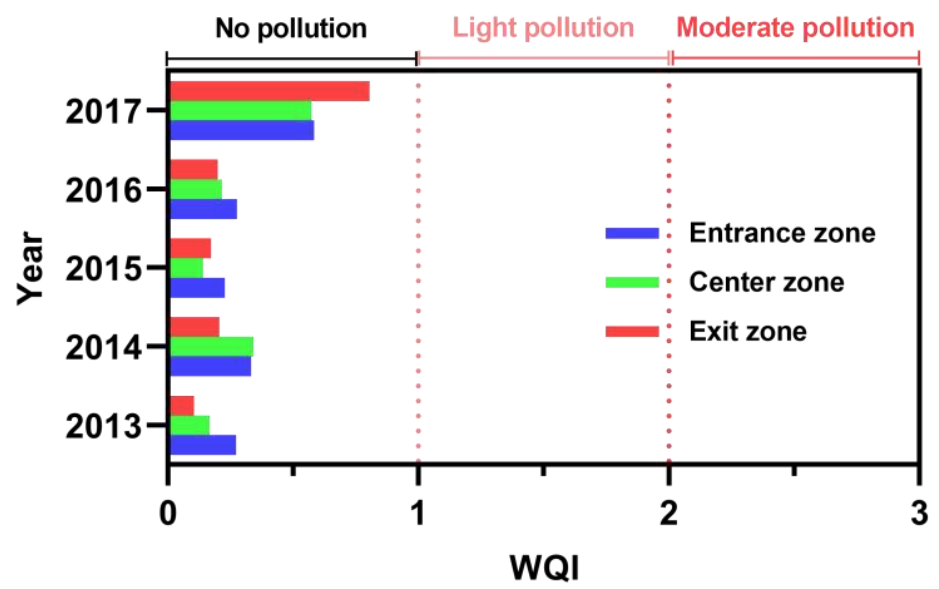

731

732 Fig. 3 Evaluation of water-quality index of the overlying water in different zones (entrance,

733 center, and exit zones) of Lake Wuliangsuhai within 2013-2017. 

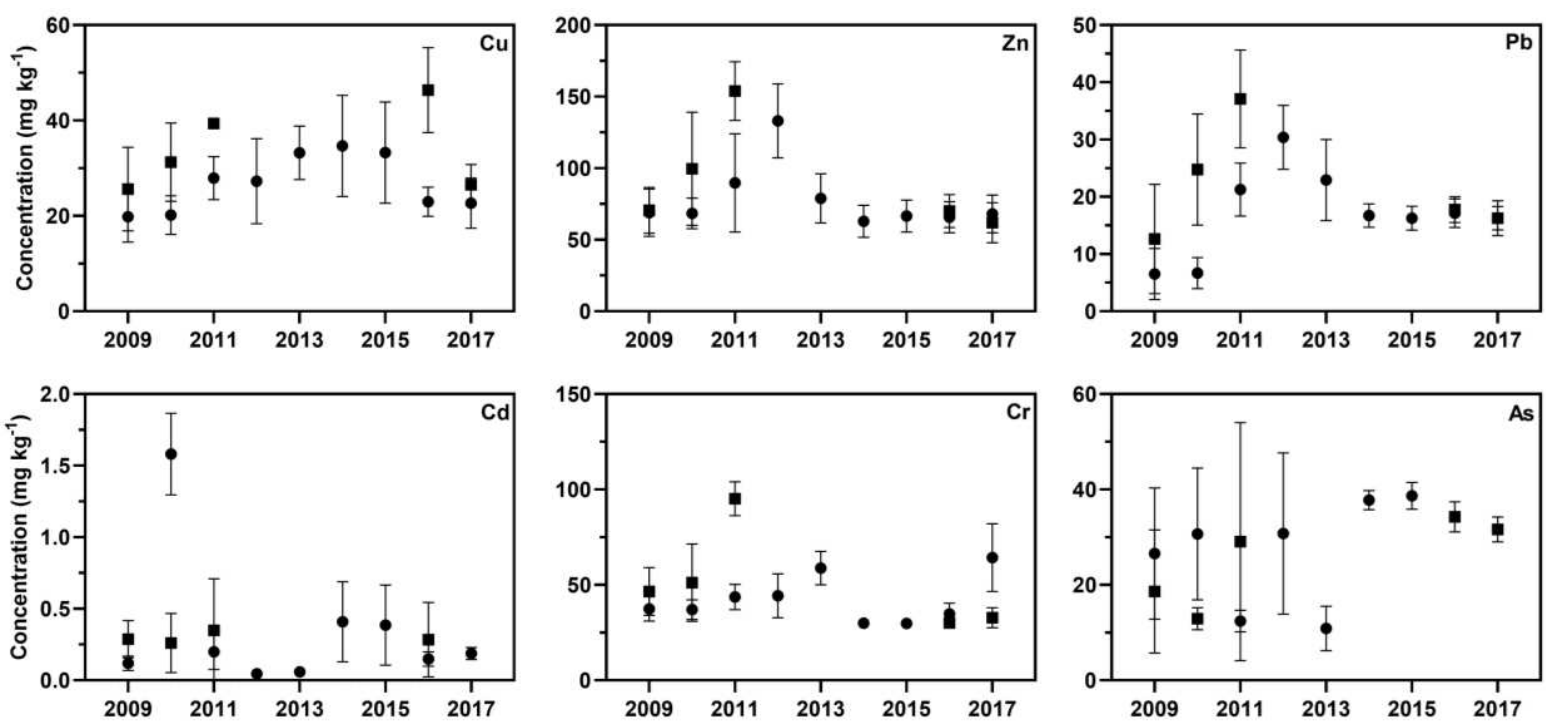

735 Fig. 4 Average concentration and SD of heavy metals and As in sediment of Lake

736 Wuliangsuhai. Note: the $\mathrm{x}$-axis represents the sampling date (2009-2017). (Different points

737 corresponding to the same year represent different scholars) 
(a) Entrance zone

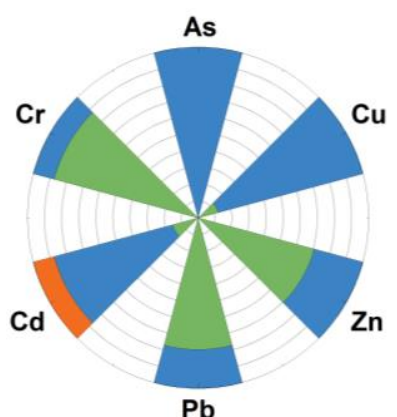

(b) Center zone

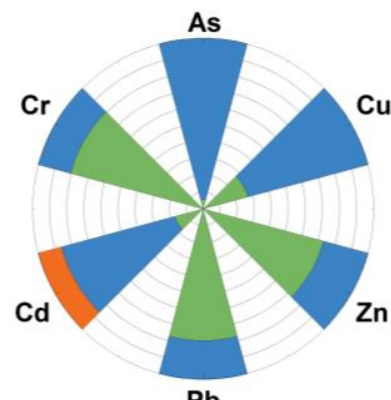

$\mathrm{Pb}$ (c) Exit zone

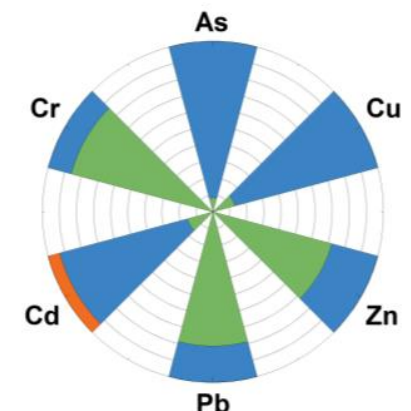

$\mathrm{Pb}$

739 Fig. 5 Geoaccumulation index ( $\left.I_{\text {geo }}\right)$ for heavy metals and As in the entrance, center, and exit 740 zones of Lake Wuliangsuhai. 

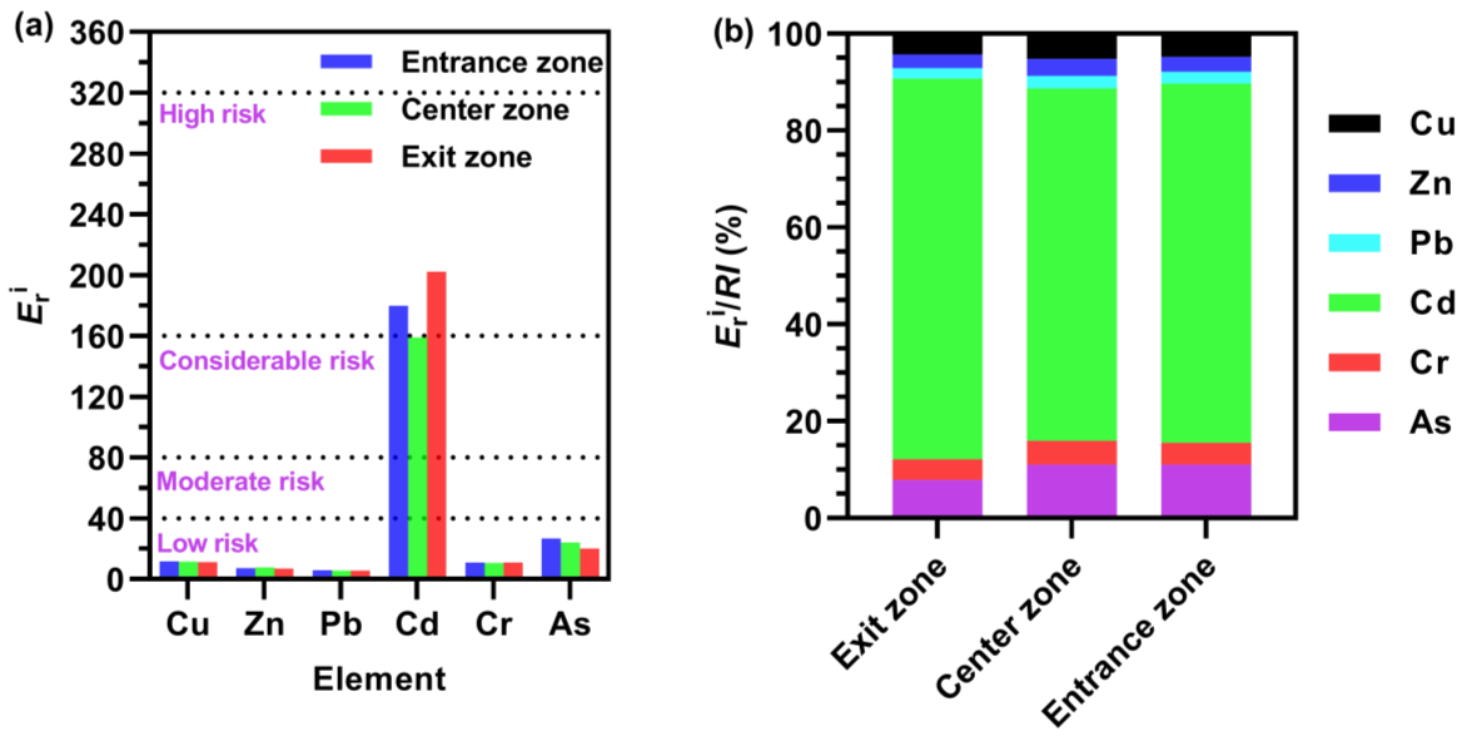

741

742 Fig. 6 Potential ecological risk index (RI) caused by heavy-metal and As pollution at the

743 entrance, center, and exit zones of Lake Wuliangsuhai. (a) Ecological-risk coefficient values of

744 a single heavy-metal element and As in different zones of the lake. (b) Contributions of

745 respective heavy metal and As to $R I$. 

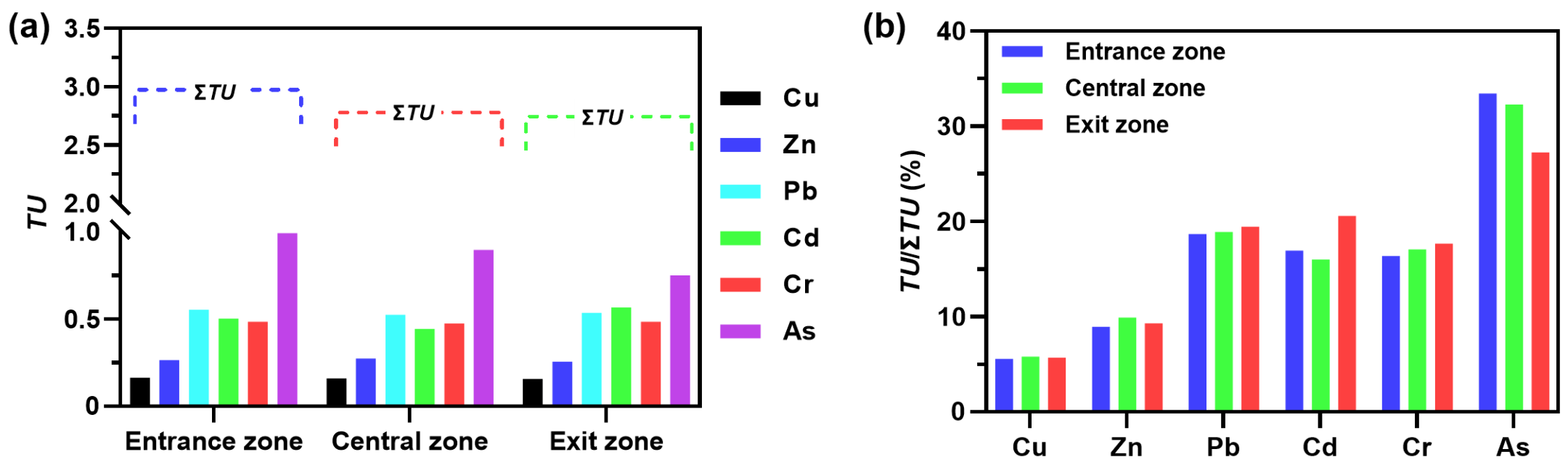

Fig. 7 Toxicity units (TU's) caused by heavy-metal and As pollution at the entrance, center, and exit zones of Lake Wuliangsuhai. (a) TU of a single heavy-metal element and As; blue, red, and green dotted lines represent the sum $T U$ 's of the lake entrance, center, and exit zones, respectively.

749 (b) Contributions of respective heavy metal and As to $T U$. 


\section{Supplementary Files}

This is a list of supplementary files associated with this preprint. Click to download.

- 3SupplementaryMaterials.docx 